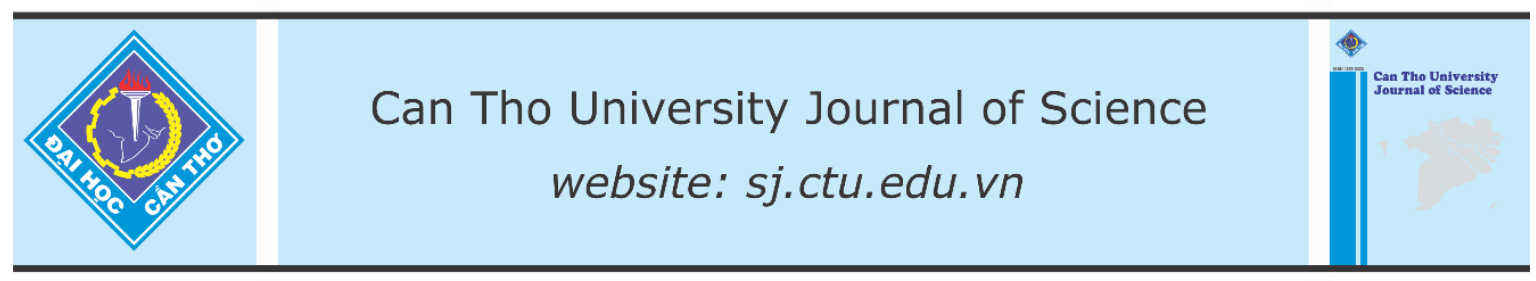

DOI: 10.22144/ctu.jen.2020.018

\title{
The dietary supplement efficiency of essential oil of chive (Allium macrostemon) on the productivity and health performance of broilers
}

\author{
Phan Vu Hai*, Ho Thi Dung, Tran Ngoc Liem, Nguyen Dinh Thuy Khuong, Pham Hoang Son \\ Hung and Nguyen Xuan Hoa \\ College of Agriculture and Forestry, Hue University, Vietnam \\ *Correspondence: Phan Vu Hai (email: phanvuhai@hueni.edu.vn)
}

\section{Article info.}

Received 29 June 2020

Revised 07 Sep 2020

Accepted 30 Nov 2020

\section{Keywords}

Broiler, chive, diarrhea, essential oil, respiratory syndrome

\begin{abstract}
This experiment was conducted to study the effect of chive essential oil (Allium macrostemon) (CEO) on the production and health of broilers. Oneday -old roosters (Ross 308) were allocated to 4 treatments with 3 replications (10 birds/replication). The experiment consisted of control group (CT) with a basal diet and T1, T2 and T3 groups with the supplement in the basal diet by levels of CEO at 100, 300 and $500 \mathrm{mg} / \mathrm{kg}$, respectively. In general, boilers supplemented with CEO had the better FCR compared to the CT. However, broilers in T2 group (300 $\mathrm{mg} / \mathrm{kg})$ showed the highest efficiency in terms of weight gain, FCR and PEI. In addition, the use of CEO in T2 and T3 group tended to reduce the incidence of respiratory and diarrhea syndrome in broilers by more than $50 \%$ of cases. It can be concluded that the supplement of CEO at the level of $300 \mathrm{mg} / \mathrm{kg}$ in the diet had improved the productive and health performance and may be a viable alternative to growth promoter in broiler production.
\end{abstract}

Cited as: Hai, P.V., Dung, H.Y., Liem, T.N., Khuong, N.D.T., Hung, P.H.S. and Hoa, N.X., 2020. The dietary supplement efficiency of essential oil of chive (Allium macrostemon) on the productivity and health performance of broilers. Can Tho University Journal of Science. 12(3): 1-6.

\section{INTRODUCTION}

The main cost of broiler production comes from feed (about $80 \%$ of total costs) (Farooq et al., 2001). Feed additives are non-nutritive products that help improve feed efficiency and thus reduce feed costs. The use of antibiotic growth promoters (AGP) in feed was actually introduced several decades ago. However, the use of antibiotics is not only limited in broiler farming but also banned in many countries for many reasons such as increasing antibiotic resistance and reducing its effectiveness of antibiotic using for medical purposes (Kabir, 2009). Therefore, in order to replace AGP, natural growth stimu- lants such as prebiotics, probiotics, synbamel, enzymes, plant extracts etc. can be used in broiler production (Borazjaniz et al., 2011).

Chive is a popular crop in the hilly and sandy areas of the central provinces of Vietnam. Unlike other plants of the Alliaceae family such as garlic and onions, the antibacterial properties of chive, especially its essential oils, have not received much research attention. It is found that chive contains a lot of bioactive substances such as diallyl sulfide (diallyl monosulfide, diallyl disulfide, diallyl trisulfide, and diallyl tetrasulfide), which are sulfur compounds that are thought to help the antibacterial activities, antioxidant, immune-stimulating (Singh et al., 
2008). Ethanol extraction from chive's bulb has antibacterial properties towards some negative gram isolated from diarrhea chicken (Hai et al., 2019). The most common of essential oil extracts is steam distillation, however, the negative effects may be caused by heat decomposition and the relatively large amount of residual oil in the water. In addition, the solvent used for extraction is usually a volatile solvent such as acetone, ethanol, methanol, ester, etc. which's residues may affect animal health. According to Staba et al. (2001), finely chopped chive bulbs are homogenized and slowly maculated in soybeans or other vegetable oils; this essential oil product contains vinyldithin, allyl sulfide, and ajoene. In this study, essential oils were extracted using vegetable oil solvents to assess their effect in vivo on growth, health, and economic efficiency in broilers.

\section{MATERIAL AND METHOD}

\subsection{Research material}

\subsubsection{Essential oil extraction from chive}

Fresh bulbs (4-5 months, planted in Hai Lang, Quang Tri) were washed, and crushed bulbs were rejected. Then, they were thinly sliced $(2-3 \mathrm{~mm})$ with herbal slicers and dried at $50^{\circ} \mathrm{C}$ for $40 \mathrm{~h}$ to achieve $10 \mathrm{~kg}$ of chive's bulb. The identification results at the Institute of Biotechnology, Hue University showed that the chive sample is in the same branch and closely related to the Allium macrostemon.

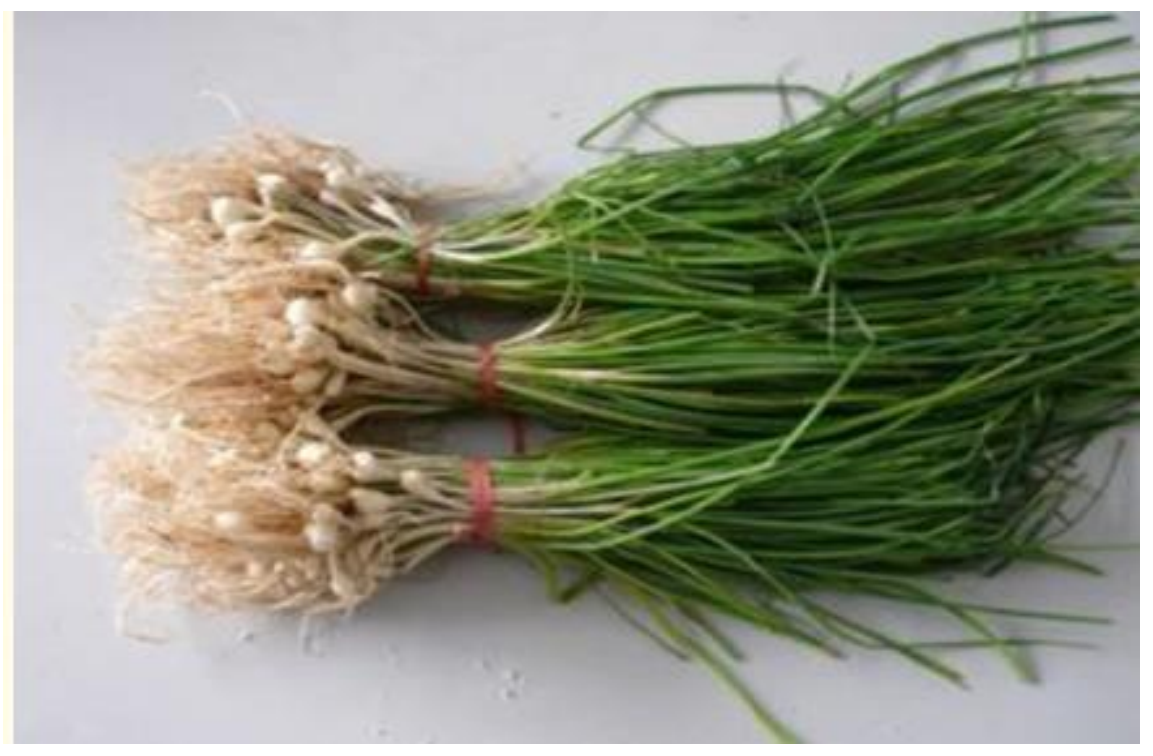

Fig. 1: Chives (Allium macrostemon) with bulbs were used

The essential oil was extracted from the bulb by using a non-volatile solvent following the instructions of Nguyen Dinh Thuan (2006) with some minor changes. Two-hundred grams of raw material is extracted in solvent (Meizan gold vegetable oil - C. Meizan CLV Ltd.) with ratio $1 / 5(\mathrm{w} / \mathrm{v})$ at $60^{\circ} \mathrm{C}, 120$ rpm shaking (Titertek Flow Laboratories - DSG 77472-00) for $48 \mathrm{~h}$. After filtering the residue, chive essential oil (CEO) was separated from the vegetable oil by ethanol $\left(\mathrm{C}_{2} \mathrm{H}_{5} \mathrm{OH}\right)$. The mixture then was distilled to recover $\mathrm{C}_{2} \mathrm{H}_{5} \mathrm{OH}$ under reduced pressure by IKA vacuum evaporator (RV10 Basic V) and then dry with sodium sulfate $\left(\mathrm{Na}_{2} \mathrm{SO}_{4}\right)$ to get the pure CEO. The extraction was conducted simultaneously 5 times and carried out continuously to extract all the chive bulbs. The extraction efficiency was $2.03 \%$ of the CEO. CEO was kept at $4^{\circ} \mathrm{C}$ for in vivo studies.

\subsubsection{Experimental animals and diets}

A total of 120 one-day-old Ross 308 broilers $(33.21 \pm 0.12 \mathrm{~g})$ were randomly assigned into four experimental treatments with three replications (10 chickens/replication). The broilers were fed with feed mixed with the main ingredients of corn, rice bran, anchovies, soybean meal $48 \%$, oyster meal, vitamin premix, mineral premix, $\mathrm{CaCO}_{3}$ powder, $\mathrm{L}$ lysine, DL-methyonin to fully meet the needs of Ross strain according to Vietnamese standards (TCVN 2265: 2007) (Table 1). Feed and water are provided with ad libitum. Temperature and relative humidity are maintained within the optimal range. 
The chicken was illuminated 23 hours/day during the experiment. The control group fed on a basal diet (recommended by Ross) and test groups were fed on a basal diet with the CEO at 100, 300, and 500 $\mathrm{mg} / \mathrm{kg}$ ( $\mathrm{T} 1, \mathrm{~T} 2$, and $\mathrm{T} 3$ respectively). The CEO is mixed in the carrier (soybean oil), then added to the baseline diet. The feed is mixed weekly in powder form. Experimental chickens were vaccinated against Marek, Newcastle, Fowl pox, and Gumboro.

Table 1: Ingredient and nutrient composition of the experimental diets

\begin{tabular}{lll}
\hline Nutritional ingredients & $1-21$ days old & $22-42$ days old \\
Metabolizable energy $\left(\mathrm{kcal} \mathrm{kg}^{-1}\right)$ & 2850.00 & 2950.00 \\
Crude Protein (\%) & 22.50 & 20.00 \\
Calcium (\%) & 1.00 & 0.96 \\
Phosphorus (\%) & 0.48 & 0.43 \\
Lysine (\% & 1.20 & 1.10 \\
Methionine (\%) & 0.46 & 0.44 \\
\hline
\end{tabular}

\subsection{Experimental indicators}

Chicken productive performance: Feed intake and weight gain were measured at 10,24, and 42 days of age; and feed conversion ratio (FCR) was feed intake per $\mathrm{kg}$ weight gain.

Chicken health: Mortality is monitored daily. Incidence of diarrhea syndrome (DS) or respiratory syndrome (RS): number of chickens suffering from diarrhea or respiration/total number of chickens observed daily.

PEI (Performance Efficiency Index) = Body weight at the end (g) x Survival rate (\%) / Number of days raised (days) * FCR (Andrade et al., 2006)

\subsection{Statistical analysis}

Data were statistically analyzed with ANOVA analysis using SPSS (version 26.0) according to the general linear correlation model (GLM). Statistical algorithm: $y \mathrm{ij}=\mu+\mathrm{Ci}+$ eij; Where: $y \mathrm{ij}=$ dependent variable; $\mathrm{Ci}=$ effect of CEO supplementation; $\mathrm{eij}=$ random error. The confidence interval is set at $95 \%$ confidence.

\section{RESULTS AND DISCUSSION}

\subsection{The effect of adding the CEO on broiler production}

In the starter stage (1to10 day-old), the results in Table 2 showed that feed intake in T3 with the highest CEO supplementation $(500 \mathrm{mg} / \mathrm{kg})$ was significantly lower than control groups $(\mathrm{P}<0.01)$, meanwhile, fewer CEO groups (100 and $300 \mathrm{mg} / \mathrm{kg}$ ) and control group were similar. During the finishing period (25-42 day-old) and the whole period (1-42 day-old) the amount of feed intake did not differ sig- nificantly among the experimental groups. It is consumed that the flavor of CEO at the high level could affect the palatability of the feed at the beginning period. Chicken weight in T2 groups supplemented with $300 \mathrm{mg} / \mathrm{kg}$ of CEO was increased significantly compared to the control group $(\mathrm{P}<0.05)$. In general, FCR was significantly improved in all groups with CEO compared to control groups $(\mathrm{P}<0.001)$ within 42-day period. Using CEO at $500 \mathrm{mg} / \mathrm{kg}$ (T3) caused weight loss $(\mathrm{P}<0.01)$, so FCR was improved for $\mathrm{T} 2$ group compared to $\mathrm{T} 3$ group $(\mathrm{P}<0.05)$. In this study, weight gain improvement was not linear. Chickens in T3 group had lower feed intake and as consequence the improved overall FCR (1-42 dayold) was observed in comparison to the control group.

Similarly, Agostini et al. (2012) found that chicken growth supplemented with a diet of clove essential oil at 100 and $200 \mathrm{mg} / \mathrm{kg}$ when fed a diet with different levels of clove oil $(0 ; 100 ; 200 ; 1,000$ and $2,500 \mathrm{mg} / \mathrm{kg}$ ). Ertas et al. (2005) found better growth results in broilers fed 100 or $200 \mathrm{mg} / \mathrm{kg}$ of essential oil mixture (marjoram, clove and star anise) compared to the $400 \mathrm{mg} / \mathrm{kg}$ group.

PEI is a general evaluation index of economic and technical indicators. The higher the PEI, the greater the economic efficiency, normally the PEI in industrial chicken production should be greater than 70 (Andrade et al., 2006). In this experiment, PEI of 296,15 in T2 group (300 mg/kg CEO) was significantly higher than that in the remaining groups $(\mathrm{P}<0.05)$ showing highest economic efficiency.

In general, the supplement of CEO with the level of $300 \mathrm{mg} / \mathrm{kg}$ in T2 group showed the best efficiency with regards to FCR, weight gain and PEI. 
Table 2: Effect of CEO supplemented on daily diet in the broiler production

\begin{tabular}{|c|c|c|c|c|c|c|c|}
\hline & Days old & Control group & $\begin{array}{r}\mathrm{T1} \\
(100 \\
\mathrm{mg} / \mathrm{kg}) \\
\end{array}$ & $\begin{array}{r}\mathrm{T} 2 \\
(300 \\
\mathrm{mg} / \mathrm{kg})\end{array}$ & $\begin{array}{r}\text { T3 } \\
(500 \mathrm{mg} / \mathrm{kg})\end{array}$ & SEM & P-value \\
\hline \multirow{4}{*}{ 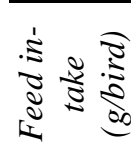 } & $1-10$ & $305^{\mathrm{a}}$ & $304^{\mathrm{a}}$ & $293^{\mathrm{ab}}$ & $278^{\mathrm{b}}$ & 5.10 & 0.007 \\
\hline & $11-24$ & 1316 & 1301 & 1290 & 1289 & 14.3 & 0.213 \\
\hline & $25-42$ & 2436 & 2362 & 2361 & 2352 & 36.0 & 0.092 \\
\hline & $1-42$ & $4081^{\mathrm{a}}$ & $3968^{a b}$ & $3966^{\mathrm{ab}}$ & $3941^{b c}$ & 37.5 & 0.021 \\
\hline \multirow{4}{*}{ 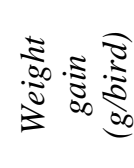 } & $1-10$ & $173^{b}$ & $183^{\mathrm{ab}}$ & $199^{\mathrm{a}}$ & $187^{\mathrm{ab}}$ & 6.52 & 0.025 \\
\hline & $11-24$ & $748^{\mathrm{a}}$ & $735^{\mathrm{ab}}$ & $756^{\mathrm{a}}$ & $689^{\mathrm{bc}}$ & 16.6 & 0.005 \\
\hline & $25-42$ & $1201^{\mathrm{b}}$ & $1236^{\mathrm{ab}}$ & $1292^{\mathrm{a}}$ & $1223^{\mathrm{ab}}$ & 25.7 & 0.044 \\
\hline & $1-42$ & $2121^{\mathrm{b}}$ & $2158^{\mathrm{b}}$ & $2259^{\mathrm{a}}$ & $2131^{\mathrm{b}}$ & 34.6 & 0.004 \\
\hline \multirow{4}{*}{$\underset{0}{0}$} & $1-10$ & $1.78^{\mathrm{a}}$ & $1.66^{\mathrm{a}}$ & $1.48^{\mathrm{b}}$ & $1.50^{\mathrm{b}}$ & 0.04 & 0.0004 \\
\hline & $11-24$ & $1.75^{\mathrm{ab}}$ & $1.77^{\mathrm{ab}}$ & $1.71^{\mathrm{b}}$ & $1.88^{\mathrm{a}}$ & 0.04 & 0.031 \\
\hline & $25-42$ & 2.03 & 1.91 & 1.82 & 1.95 & 0.04 & 0.072 \\
\hline & $1-42$ & $1.92^{\mathrm{a}}$ & $1.84^{\mathrm{b}}$ & $1.74^{\mathrm{c}}$ & $1.84^{\mathrm{b}}$ & 0.02 & 0.0006 \\
\hline \multicolumn{2}{|l|}{ PEI } & $253.71^{b}$ & $260.81^{b}$ & $296.15^{\mathrm{a}}$ & $265.21^{\mathrm{b}}$ & 7.95 & 0.018 \\
\hline
\end{tabular}

$a b c$ : Means on the same row followed by different superscripts are significantly different $(P<0.05)$

\subsection{The effect of adding a CEO to the health of broilers}

The two most common syndromes that occur in broilers are DS and RS. The results in Fig. 2 showed that chickens with DS and RS were quite high, about 17.4-20.69\%, especially at the age of 21-42 days, the prevalence of DS was $37.93 \%$. The high mortality rate $(10 \%)$ in the control group was also occurred during this period. On the whole, the use of CEO in the diet had tended to reduce the incidence of DS and RS at $300 \mathrm{mg} / \mathrm{kg}$ (T2) and $500 \mathrm{mg} / \mathrm{kg}$ (T3) by more than $50 \%$ of infected broilers. A statistically significant difference $(\mathrm{P}<0.05)$ was found only at the period of $21-42$ days old $(6.9 \%$ in T3 and $10.2 \%$ in T2 compared to $37.93 \%$ in the control group) for DS. Besides, the mortality rate in $\mathrm{T} 2$ and $\mathrm{T} 3$ was lower than the control group but the difference was not statistically significant $(\mathrm{P}<0.05)$. Most broilers were infected due to the winter weather in Hue City, especially during periods of cold air and high humidity. Therefore, adding the CEO had a positive sign in preventing DS and RS in this period. It is likely that adverse weather is associated with the possible presence of bacteria such as E. coli and Salmonella caused high DS in broilers and the CEO had an antibacterial effect towards these bacteria.

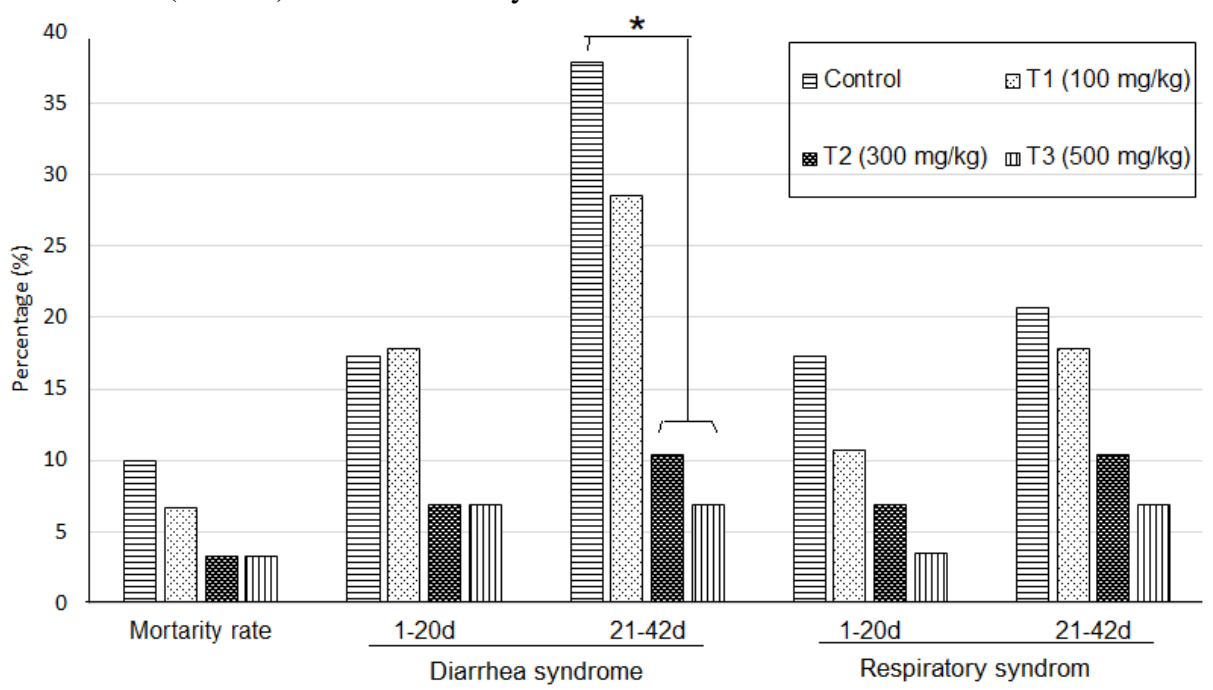

Fig. 2: Effect of CEO supplementation on the health of experimental chickens

*statistical differences $(P<0.05)$ 
Bacteria are the main cause of respiratory and digestive diseases in poultry species that cause heavy economic losses of broiler production worldwide (Samy and Naguib, 2018). Possible pathogens are Escherichia coli (Murthy et al., 2008), Ornithobacterium rhotracheale (Lister and Barrow, 2008) associated with respiratory tract infection, or by $M y$ coplasma gallisepticum that causes chronic respiratory disease (CRD) in poultry (Levisohn and Kleven, 2000). With the gastrointestinal tract, the main pathogenic bacteria are E. coli and Salmonella and to an increasingly difficult to control level (Azam et al., 2019). On the previous study (Hai et al., 2019) we found that ethanol extract of chive had potential antibacterial activities against pathogens/Gram-negative bacteria (E. coli and Salmonella spp.) isolated from diarrhoea chickens. Besides, Mnayer et al. (2014) evaluated the antibacterial activity of chive's oil against different gramnegative and gram-positive bacterial strains. According to the author, the high compound of sulfur in the oil effects on the high susceptibility to bacteria. In addition to antibacterial properties, the pharmacological ingredients in CEO have the ability to stimulate the animal digestive system, antioxidants, antifungal, anti-parasitic and anti-inflammatory; thereby improving the growth and health of the chickens.

\section{CONCLUSIONS}

The groups of CEO supplements at 100, 300 and $500 \mathrm{mg} / \mathrm{kg}$ showed a better production efficiency, especially the FCR compared to the control treatment. The level of $300 \mathrm{mg} / \mathrm{kg}$ showed the highest efficiency. The CEO supplementation at 300 and $500 \mathrm{mg} / \mathrm{kg}$ had a positive effect on the health of the experimental broilers, as shown by the improvement in the survival rate and the incidence of DS and RS. The results of this study show that the CEO extracted with the vegetable oil solvent at a supplement of $300 \mathrm{mg} / \mathrm{kg}$ in feed may be a viable alternative to growth promoter in chicken production.

\section{REFERENCES}

Agostini, P.S., Solà-Oriol, D., Nofrarías, M., Barroeta, A.C., Gasa, J., Manzanilla, E.G.,2012. Role of infeed clove supplementation on growth performance, intestinal microbiology, and morphology in broiler chicken. Livestock Science. 147(1-3): 113-118.

Andrade, M., Andrade, L., Xavier, S., Café, M., Leandro, N., 2006. Performance, nutrient balance and retention and biometrical measures of digestive organs of broilers fed different dietary protein levels in the pre-starter period. Revista Brasileira de Zootecnia. 35 (6): 2350-2358.

Azam, M., Mohsin, M., Sajjad Ur, R., Saleemi, M. K., 2019. Virulence-associated genes and antimicrobial resistance among avian pathogenic Escherichia coli from colibacillosis affected broilers in Pakistan. Tropical Animal Health and Production. 51(5): 1259-1265.

Borazjaniz, M., Eslami, M., Bojarpour, M., Chaji, M., Fayazi, J., 2011. The effect of clove and oregano on economic value of broiler the effect of clove and oregano on economic value of broiler chickens diet under hot weather of Khuzestan. Journal of Animal and Veterinary Advances. 10(2): 169-173.

Ertas, O.N., Guler, T., Çiftçi, M., DalkIlIç, B., Simsek, U.G., 2005. The effect of an essential oil mix derived from oregano, clove and anise on broiler performance. International Journal of Poultry Science. 4(11): 879-884.

Farooq, M., Mian, M., Asghar, A., 2001. Factors affecting cost of production and net profit per broiler in the subtropics. Livestock Research for Rural Development. 13(1): 1-5.

Hai, P.V., Van, H.T.H., Chao, N.V., Khuong, N.D.T., Le, T.T.T., Anh, L.X., Dung, H.T., Hung, P.H.S., 2019. Antimicrobial activity of chives and ginger extract on Escherichia coli and Salmonella spp. isolated from broiler chickens. Hue University Journal of Science: Agriculture and Rural Development. 128(3B): 105-111.

Kabir, S.M.L., 2009. The role of probiotics in the poultry industry. International Journal of Molecular Science. 10(8): 3531-3546.

Levisohn, S., Kleven, S.H., 2000. Avian mycoplasmosis (Mycoplasma gallisepticum). Revue scientifique et technique (International Office of Epizootics). 19 (3): 425-442.

Lister, S. A., Barrow P., 2008. Chapter 8 - Enterobacteriaceae. In: Pattison M., McMullin P. F., Bradbury J.M., Alexander D.J. (Eds.). Poultry Diseases $\left(6^{\text {th }}\right.$ Edition). Elsevier Ltd. Edinburgh, pp. 110-145.

Mnayer, D., Fabiano-Tixier, A.S., Petitcolas, E., Hamieh, T., Nehme, N., Ferrant, C., Fernandez, X., Chemat, F., 2014. Chemical composition, antibacterial and antioxidant activities of six essentials oils from the Alliaceae family. Molecules (Basel, Switzerland). 19(12): 20034-20053.

Murthy, T., Dorairajan, N., Amirthalingam B.G., Manicavasaka D.A., Saravanabava, K., 2008. Pathogenic bacteria related to respiratory diseases in poultry with reference to Ornithobacterium rhinotracheale isolated in India. Veterinarski Arhiv. 78 (2): 131140.

Nguyen Dinh Thuan, 2006. Essential oils and some medicinal herbs contain essential oils. In: Dong, N.T. (Eds.). Research medicine from herbs. Science and 
Technology Publisher. Hanoi, pp. 223-253. (in Vietnamese)

Samy, A., Naguib, M.M., 2018. Avian respiratory coinfection and impact on avian influenza pathogenicity in domestic poultry: field and experimental findings, Veterinary Sciences. 5(1):23.

Singh, G., Kapoor, I.P., Singh, P., de Heluani, C.S., de Lampasona, M.P., Catalan, C.A., 2008. Chemistry, antioxidant and antimicrobial investigations on essential oil and oleoresins of Zingiber officinale. Food and Chemical Toxicology. 46(10): 3295-3302.

Staba, E.J., Lash, L., Staba, J.E., 2001. A commentary on the effects of garlic extraction and formulation on product composition. The Journal of Nutrition. 131(3s): 1118S-1119S. 